\title{
Environmental marketing strategy in classified hotels
}

\author{
Odai Falah Mohammad AL-Ghaswyneh ${ }^{a^{*}}$
}

${ }^{a}$ Department of Marketing, Northern Border University, Saudi Arabia

\section{H R O N I C L E A B S T RACT}

Article history:

Received: January 20, 2020

Received in revised format:

March 252020

Accepted: April 26, 2020

Available online:

April 26, 2020

Keywords:

Environmental Marketing

Market Mix

Classified hotels

Aqaba Special Economic Zone

Authority (ASEZA)

\begin{abstract}
This study investigates the environmental marketing strategy in hotel industry. The study also chooses Aqaba Special Economic Zone Authority (ASEZA) as a case study. The study population consists of a tourist in Aqaba. The study distributes 1000 questionnaires and manages to collect 900 properly filled ones and determines 800 as valid questionnaires. All questions are designed in Likert scale and the results are analyzed using different statistical test. The results indicate that the size of the hotel, the implementation of the recycling program, in addition to saving money, increases customer satisfaction.
\end{abstract}

\section{Introduction}

Environmental concerns have emerged as government policy in economically developed countries. Business organizations at this stage are looking at environmental legislation with suspicion since they are associated with cost increases, and because of their impacts on operations and reduced profits. The equation was not enough until the late 1980s, when academics applied their research on ways that could be used by organizations to improve their performance through emphasizing the environmental quality of their products and services by developing more environmentally sensitive products and stimulating the organization to work on these environmental characteristics through which they seek to provide a clean environmental product (Saleh \& Jawabreh, 2020; Chan, 2013). The concept of marketing performance reflects the degree of success or failure of the organization through its pursuit of its own objectives. There are many indicators to measure performance, including: customer satisfaction, market share, profitability, efficiency and effectiveness. The concept of "green marketing mix" expresses a set of tools and marketing elements that the establishment works to achieve through the process of inclusion and integration between them, in order to serve the target market and achieve the objectives of the facility with no environmental damage (Ann et al., 2006; Alananzeh et al., 2018). The concept of green marketing has been emerged as one of the data of the social orientation phase of marketing during the seventies of the last century as a precautionary phase that imposes, primarily on producers and marketers, the need to care for and preserve natural and environmental resources from the annihilation and pollution, by providing a better life for society. There is no doubt that this new philosophical vision of the trends of green marketing has found its implications and applications in the emergence of a new concept in the way of thinking and philosophy governing the marketing activity, known as green marketing (Cengiz et al., 2018; Chan \& Hsu, 2016). The concept of "product" is supposed to be developed to cope with environmental trends. Organizations should rely heavily on raw resources that are environmentally friendly in their production processes and do not consume too much raw materials. The marketing mix is also defined as a set of tactical marketing tools or elements that can be controlled, namely the product, price, promotion and location that the organization mixes together to achieve the desired response in the target market. It is clear from the 
previous definitions that they focused mainly on customer satisfaction, increasing sales growth and profitability of the organization with no interest in the environment; these are the most important differences between the traditional marketing mix and the green marketing mix. Thus, the researcher believes that the green marketing mix is a set of marketing tools and elements between which the organization is trying to achieve integration and association in order to serve the target market and achieve the objectives of the organization without harming the natural environment (Baker et al., 2014; Berezan et al., 2013).

Social responsibility in the marketing framework is embodied and evident in the various marketing mechanisms and subactivities that makes it up. Talking about an institution that bears its social responsibility in marketing means a comprehensive responsible obligation for the various components and decisions of this institution's work, which requires economic institutions to strive to achieve social welfare and better life of the community in its various categories through marketing, which is a link between the institution and the community (Alsarayreh et al., 2011; Arthur et al., 2009). Product development plays a crucial role in the competitiveness of organizations, especially advanced ones. They operate in an environment that requires them to develop their products and market new products always. The role of marketing is to deliver technology benefits to the customer in order to sell products; this is from the point of view of the organization that is geared towards green strategies. A product should meet or exceed the expectations of the customers by delivering them the value they were promised and by giving them environmental benefits as secondary advantages of the product. Usually, customers do not have the experience or the ability to recognize the environmental or consumer value of the product. This creates confusion, uncertainty and inability to customers' understanding (Chan, 2013; Chen \& Schwartz, 2008). These products must be of good quality and satisfy the expectations of customers, especially as they become more complicated. Customers also expect products with high-value, low-price and attractive shape, they have increasingly added environmental standards to their lists of expectations. Organizations are expected to respond to environmental legislation, manufacture and market products while minimizing negative environmental impacts as possible.

Kotler defined green product as "developing products to offer customers without environmental damage". In line with the evolution of the concept of marketing and the interest in the environment in marketing activities, a new concept started emerging under the title of "green marketing" as a modern approach to marketing management. Although there is no indication of a clear start to green marketing as a marketing portal, there are those who suggest that the concept of green marketing is a marketing approach that began after the publication of the green consumer guide in the USA in 1989. This guide included types of products that do not harm the environment or the consumer and we do not find an intellectual resistance in agreeing with these views in determining the emergence of green marketing. Nowadays, our world is living the so-called green revolution, which came as a natural reaction to the increasing and unregulated consumption of natural resources of the environment until ecological diseases of the era came to the surface suddenly, such as climate change, the increase of the ozone hole, and the spread of acid rain (Zhao \& Zheng, 2000; Alananzeh et al., 2015; Kotler \& Keller, 2016). Social responsibility has emerged as one of the solutions to the problems known to society, which were the result of the productive or marketing process and its negative effects, such as the depletion of natural resources, lack of social services and the aggravation of the problems of poverty and unemployment, so it became necessary for economic institutions to move away from paying attention to profits as the sole objective try to maximize in all circumstances and work on adopting business ethics and social responsibility when dealing with their internal and external environment. In setting prices, the organization must be sure that the customer can pay this price and in return feels receiving a good benefit to his satisfaction. Although many green products cost more because of the economics of the field and because of trying to maintain quality (Mathur \& Mathur, 2000; Osarenkhoe, 2003).

Prices and products have a direct impact on customers, the lower the prices, the more the number of customers of the organization and their loyalty to it, with consistent quality of the product. When the organization offers a discount to customers as they buy its products, this has an important role in increasing their loyalty and commitment (Rand \& Rust,2011). Many definitions of the traditional marketing mix have been reported. Generally traditional marketing mix can be defined as a set of elements; product marketing activities, distribution, promotion and pricing through which the organization can meet the needs and desires of customers within its market, or as a set of variables or integrated elements managed by marketers to serve the target market and to achieve the goals of the organization (Xiong \& Hu, 2010). Jawabreh (2109) expresses his view that the philosophy of customer-focus includes the marketing concept that arose from the belief that an acceptable percentage of sales and satisfactory returns on investment can be achieved through identifying, predicting, and satisfying the needs and desires of the consumer. Alsarayreh et al. (2011) indicate that the objectives of the organization can be fulfilled by meeting the needs of customers beyond other competitors. The definition of a green marketing mix differs from the definition of a traditional marketing mix, due to the targeted use of the elements of the mix. The green marketing mix has been defined as: "a set of marketing tools and elements that the organization works to achieve integration and association between them, in order to serve the target market and achieve the objectives of the organization without harming the natural environment". There are a number of social and political variables that need to be taken into account when institutions adopt the philosophy of green marketing, and these elements have a direct impact on the green marketing mix, as it helps to adapt and harmonize the elements of the mix (Dholakia \& Bagozzi, 2001).

The product is of great importance in the green marketing approach because most of the efforts for environmental orientation are based on the producers. This requires permanent and continuous cooperation between the marketing and production departments, the marketing department should constantly provide information on the trends and preferences of green consumers 
regarding environmental characteristics. The production department should reconcile the required environmental standards with the available technical standards, so that the best formulation for the production and delivery of these products can be reached. This is what is known as the eco-friendly design. The green manufacturing process is sensing various environmental issues and taking them into account at the production operations, and this can be done depending on the following principles: making the products recyclable by designing products that make it possible to reuse their components again, reusing some materials through recycling, and using environmentally friendly raw materials or ingredients by focusing on the research process and development. When presenting green products, the characteristics of the original product must be maintained with distinction to the requirements and required environmental qualities (DiPietro \& Partlow, 2013; El Dief \& Font,2010; Fraj et al., 2011; Fuller, 1999). McDonald has replaced fast-food packaging with paper instead of polyester filaments, noting that consumers are increasingly worried about it, as it would later have negative effects on the ozone layer when burned in landfills (Ginsberg \& Bloom, 2004). Green marketing can be considered as the best solution for organizations to face the pressures, and compliance with environmental standards in the field of business. The concept of green marketing has wide dimensions beyond the achievement of the objectives of the organization only, it includes green marketing practices to meet and satisfy the needs and desires of consumers and achieve their welfare by providing environmentally safe products that contribute to preserving the environment, as well as the continuation of the foundation's activities and achieving profits without any restrictions or obstacles. Therefore, the adoption of the concept of green marketing has positive repercussions on both the environmental, social and economic dimensions, in order to achieve sustainable development, as well as achieving the continuous competitive advantage of the institution and giving it a strong competitive position in the market, since green marketing improves the image of the enterprise to consumers, in addition to reducing the depletion of non-renewable natural resources for future generations to make the world a better place to live (Kapelianis \& Strachan, 1996; Kim et al., 1997). In the light of these variables, the concept of green marketing came as a contemporary concept that addresses the environmental and ethical problems resulting from the negative practices of traditional marketing. It is also a response to global concern towards the environment through smart consumption which gives a clean environment. Hence, the economic institutions began to develop and define its options and strategies, including the marketing aspect, and translate this into the introduction of green products i.e. environmentally friendly (Jawabreh \& Al Sarayreh, 2017).

\section{Methodology}

The study population consists of a tourist in Aqaba and the sample study included 1000 questionnaires which were distributed, and 900 questionnaires which were retrieved. The number of questionnaires valid for analysis was 800 . The method of collection of data is as follows,

a. Primary Sources: The questionnaire was used as the main source for gathering information related to environmentally friendly marketing strategies in Aqaba Special Economic Zone hotels.

b. Secondary sources: The theoretical framework of the study was prepared based on Arabic and English books and references that dealt with the study variables, in addition to the letters and periodicals that touched on the subject.

The field study aimed at demonstrating the possibility of better green marketing strategies in Aqaba Special Economic Zone hotels. Therefore, a questionnaire was prepared for the study in a manner that fits with this goal, each of them consisted of two parts, as follows:

Part I: Includes an explanatory introduction to the general objective of the questionnaire demographic variables.

Part II: includes the allocations for collecting data related to the independent factors of the study sample "the questionnaire".

A questionnaire has been prepared so that the respondent would mark each of the axis paragraphs, as there are columns for each paragraph reflecting five levels of response or approval; each level represents a certain weight upward from 1 to 5 according to the Likert scale. Table 1 indicates that "Aqaba hotels give priority to environmental products" has received the highest arithmetic average of (3.28) and the fifth paragraph "Products provided by Aqaba hotels have little effect on the natural environment" obtained the same arithmetic average. While the first paragraph got a standard deviation (1.37) and the second a deviation of (1.34), which is evidence of the hotels' commitment in Aqaba in the purchase of supplies of environmentally friendly materials. The second paragraph, "Aqaba Hotels is working to recycle the products used by hotels" has obtained the lowest average arithmetic value of (2.32) and a standard deviation (1.27), and the researcher attributes the reason for this result to the fact that Aqaba hotels are interested in the local product in order to encourage tourism and to introduce tourists to local products, whether they are heritage or modern. The researcher attributes the lack of use of the recycling of used products to the weak point in waste management in Jordan. It is in the stage of sorting at the source of the waste and then recycling, since this process requires a human effort and modern techniques that provide the opportunity to divide the waste and determine the percentage of recyclable ones. Aqaba hotels classified as waste sorting process, but there is no integrated waste management system in the Aqaba Special Economic Zone that includes reducing the volume of waste and reusing it in the same place or recycling it to another product and then recovering it in the Economic Production Department. Jordan does not have an integrated recycling system, but rather various attempts by civil organizations, as well as from the private sector. These attempts were on a narrow geographical level due to the lack of material capabilities, especially the availability of 
sorting and collection containers, equipment and cars (Jawabreh, 2017a). In economic terms, the total cost of waste management in the Greater Amman Municipality is estimated at 12 million dinars, while the total losses amount to 7 million dinars annually. While the Greater Amman Municipality generates reserve revenues from the reprocessing activities of cardboard, white paper, plastic products, iron and aluminum - although it is very limited, the participation of the private sector in managing solid waste is relatively modest in Jordan.

Table 1

Means Standard divination (Product, Price, Place and Promotion)

\begin{tabular}{|c|c|c|c|}
\hline $\mathbf{N}$ & Items & Means & SD \\
\hline & Product & 2.98 & 1.39 \\
\hline 1 & Aqaba hotel uses environmentally friendly supplies and consumable products for our products & 2.32 & 1.27 \\
\hline 2 & Aqaba hotels recycle the products inspired by the hotel & 2.76 & 1.36 \\
\hline 3 & Aqaba hotel gives priority to offering ecological products. & 3.28 & 1.37 \\
\hline 4 & Aqaba hotel is geared to design, develop and offer its product in an environmentally friendly way. & 3.28 & 1.34 \\
\hline \multirow[t]{2}{*}{5} & Aqaba hotel provides its product in a way that minimizes its impact on the natural environment. & 3.27 & 1.32 \\
\hline & Price & 3.00 & 1.37 \\
\hline 6 & Aqaba hotel tends to build environmental compliance costs into the service price. & 2.90 & 1.42 \\
\hline 7 & $\begin{array}{l}\text { Aqaba hotel takes advantage of any cost savings derived from using environmentally friendly practices } \\
\text { to offer better prices. }\end{array}$ & 2.86 & 1.40 \\
\hline 8 & $\begin{array}{l}\text { Aqaba hotel takes advantage of the financial success of several environmentally friendly products to re- } \\
\text { duce its prices. }\end{array}$ & 3.11 & 1.35 \\
\hline \multirow[t]{2}{*}{9} & $\begin{array}{l}\text { Aqaba hotel offers competitive prices to our customers as a result of the environmentally friendly prac- } \\
\text { tices implemented }\end{array}$ & 3.15 & 1.30 \\
\hline & Place & 2.90 & 1.37 \\
\hline 10 & $\begin{array}{l}\text { Aqaba hotel encourages suppliers/vendors and agents/representatives to embrace and reflect environ- } \\
\text { mental responsibility. }\end{array}$ & 2.88 & 1.38 \\
\hline 11 & $\begin{array}{l}\text { Aqaba hotel shows a preference for suppliers and strategic partners that embrace environmental respon- } \\
\text { sibility. }\end{array}$ & 2.87 & 1.30 \\
\hline 12 & $\begin{array}{l}\text { Aqaba hotels are careful when choosing supplies and consumer products to ensure they are environmen- } \\
\text { tally friendly }\end{array}$ & 2.91 & 1.40 \\
\hline \multirow[t]{2}{*}{13} & Aqaba hotel buys supplies in bulk to reduce packaging where possible. & 2.92 & 1.41 \\
\hline & Promotion & 3.04 & 1.42 \\
\hline 14 & $\begin{array}{l}\text { We highlight our commitment to environmental preservation in our advertisements, sponsorships and/or } \\
\text { campaigns. }\end{array}$ & 2.92 & 1.43 \\
\hline 15 & $\begin{array}{l}\text { Our promotional and communicational efforts highlight and inform our customers about our environ- } \\
\text { mental efforts. }\end{array}$ & 3.05 & 1.42 \\
\hline 16 & Aqaba Hotels works in its advertising and environmental stewardship & 3.15 & 1.41 \\
\hline
\end{tabular}

Table 2

Reliability Statistics

Cronbach's Alpha .712 N of Items 16

Table 2 indicates that the Cronbach's alpha stability factor has reached 0.712 , which is an acceptable stability factor in such studies and indicates that the paragraphs were well prepared and validated by statistical methods, and the sample was randomly representative of the community.

Table 3

Hotel Size with (Product, Price, Place and Promotion)

\begin{tabular}{|c|c|c|c|c|c|}
\hline \multicolumn{2}{|c|}{ Star ratings } & \multirow{2}{*}{$\begin{array}{c}\text { Product } \\
3.0348\end{array}$} & \multirow{2}{*}{$\begin{array}{c}\text { Price } \\
3.0543\end{array}$} & \multirow{2}{*}{$\begin{array}{c}\text { Place } \\
2.8261\end{array}$} & \multirow{2}{*}{$\begin{array}{c}\text { Promotion } \\
3.0000\end{array}$} \\
\hline 1 & Mean & & & & \\
\hline & $\mathrm{N}$ & 69 & 69 & 69 & 69 \\
\hline & Std. Deviation & .69786 & .83233 & .87374 & 1.02899 \\
\hline \multirow[t]{3}{*}{2} & Mean & 3.0814 & 3.0042 & 3.2500 & 2.8927 \\
\hline & $\mathrm{N}$ & 59 & 59 & 59 & 59 \\
\hline & Std. Deviation & .99524 & .72589 & .80676 & .86755 \\
\hline \multirow[t]{3}{*}{3} & Mean & 2.8241 & 2.9440 & 2.6164 & 3.2414 \\
\hline & $\mathrm{N}$ & 58 & 58 & 58 & 58 \\
\hline & Std. Deviation & .89292 & 1.08220 & .84451 & .96487 \\
\hline \multirow[t]{3}{*}{ Total } & Mean & 2.9839 & 3.0040 & 2.8952 & 3.0412 \\
\hline & $\mathrm{N}$ & 186 & 186 & 186 & 186 \\
\hline & Std. Deviation & .86441 & .88473 & .87790 & .96552 \\
\hline
\end{tabular}

Table 3 indicates the averages and standard deviations for the fields of study (final product, price, location, and promotion) according to the classification of hotels in the Aqaba Special Economic Zone. And the four-star hotels got an average arithmetic average in terms of the final product, which reached (3.08) with a standard deviation of (0.99524). In three-star hotels the survey got the lowest arithmetic mean of (2.8241) with a standard deviation (0.89293). As for the price, the five hotels occupied Stars ranked first with a mean (3.0543) with a standard deviation of 0.833233 . As for the place, the four-star hotels got the highest average arithmetic score as well (3.2500) with a standard deviation (0.8067) and three-star hotels got the lowest arithmetic mean (2.6164) with a standard deviation (0.89770) and finally in terms of promotion, the three stars got. The highest 
arithmetic mean was (3.2414) with a standard deviation (0.96487), and four-star hotels got the lowest average arithmetic value (2.8927) with a standard deviation (0.86755). The researcher attributes these results to five-star hotels which are committed to focusing on green initiatives and green policies by monitoring and reducing consumption levels, converting environmental efforts into cost reductions and opportunities to bring in revenue while promoting corporate responsibilities. Hotel policy is supported by all employees who help define and implement environmentally friendly policies.

Table 4

Hotel Size with (Product, Price, Place and Promotion)

\begin{tabular}{|c|c|c|c|c|c|}
\hline \multicolumn{2}{|c|}{ Hotel Size } & Product & Price & Place & Promotion \\
\hline \multirow[t]{3}{*}{1} & Mean & 2.9158 & 2.8596 & 2.8202 & 3.0702 \\
\hline & $\mathrm{N}$ & 57 & 57 & 57 & 57 \\
\hline & Std. Deviation & .74924 & .89270 & .76438 & .91230 \\
\hline \multirow[t]{3}{*}{2} & Mean & 2.9176 & 3.0824 & 3.0353 & 2.9176 \\
\hline & $\mathrm{N}$ & 85 & 85 & 85 & 85 \\
\hline & Std. Deviation & .87303 & .82501 & .90234 & 1.01953 \\
\hline \multirow[t]{3}{*}{3} & Mean & 3.1400 & 3.0063 & 2.8313 & 3.2167 \\
\hline & $\mathrm{N}$ & 40 & 40 & 40 & 40 \\
\hline & Std. Deviation & .99352 & 1.02139 & .91705 & .93538 \\
\hline \multirow[t]{3}{*}{4} & Mean & 3.8000 & 3.3750 & 1.6250 & 3.5000 \\
\hline & $\mathrm{N}$ & 4 & 4 & 4 & 4 \\
\hline & Std. Deviation & .00000 & .14434 & .14434 & .57735 \\
\hline \multirow[t]{3}{*}{ Total } & Mean & 2.9839 & 3.0040 & 2.8952 & 3.0412 \\
\hline & $\mathrm{N}$ & 186 & 186 & 186 & 186 \\
\hline & Std. Deviation & .86441 & .88473 & .87790 & .96552 \\
\hline
\end{tabular}

Table 4 indicates the arithmetic mean for the four study areas (final product, price, location, and promotion). We notice from the table that hotels with size (4) obtained the highest mean (3.8) with a standard deviation (0.0000). These hotels ranked first in the two areas (price) and (place), where they obtained two arithmetic averages, respectively (3.3750) and (3.500), with two standard deviations respectively, 0.14434 and 0.5735 , while hotels occupied the size (2) in the field of location where only the first place had an average mean of 3.05 with a standard deviation of 0.90234 . The researcher attributes these results that hotel organizations are working to increase hotel occupancy rates and raise the market share, by gaining more tourists and maintaining current guests, so the hotel management must prepare a study on the number of tourists and predict the increase or decrease in the future, and they must also know the geographical distribution and demographic composition. For the population in terms of age, gender, educational and cultural level, and family income for each group, where the desire to travel and tourism varies according to the age and living style of each family. In light of this, marketing plans and promotional activities appropriate to the target market that satisfy are developed a customer loyalty. It has proven that the greater the size of the hotel, the implementation of the recycling program, in addition to saving money, increases customer satisfaction, raises employee morale and build relationships with recycling management companies in the region, and that recycling and effective waste management application can establish the hotel as a leader in the field of environmental causes, and can, in return, lead to more costs and environmentally friendly measures, including persuading hotel buyers to start purchasing recycled products, and implementing environmentally friendly initiatives will not only save money, but can lead to a serious marketing strategy. These will entice supporters to protect the environment and customers' friends of the environment favoring the organization on others.

Table 5

Chain affiliations with (Product, Price, Place and Promotion)

\begin{tabular}{|c|c|c|c|c|c|}
\hline \multicolumn{2}{|c|}{ Chain affiliations } & \multirow{2}{*}{\begin{tabular}{|c|} 
Product \\
2.9333 \\
\end{tabular}} & \multirow{2}{*}{$\begin{array}{c}\text { Price } \\
2.8214\end{array}$} & \multirow{2}{*}{\begin{tabular}{|c|} 
Place \\
2.7579
\end{tabular}} & \multirow{2}{*}{\begin{tabular}{|c|} 
Promotion \\
3.0635
\end{tabular}} \\
\hline 1 & Mean & & & & \\
\hline & $\mathrm{N}$ & 63 & 63 & 63 & 63 \\
\hline & Std. Deviation & .92979 & .95507 & .83638 & .96136 \\
\hline \multirow[t]{3}{*}{2} & Mean & 2.9219 & 3.1953 & 2.9961 & 2.9948 \\
\hline & $\mathrm{N}$ & 64 & 64 & 64 & 64 \\
\hline & Std. Deviation & .72822 & .75392 & .89697 & .93998 \\
\hline \multirow[t]{3}{*}{3} & Mean & 3.1019 & 3.1132 & 2.9434 & 3.0377 \\
\hline & $\mathrm{N}$ & 53 & 53 & 53 & 53 \\
\hline & Std. Deviation & .97793 & .85424 & .87930 & 1.04730 \\
\hline \multirow[t]{3}{*}{ Total } & Mean & 2.9839 & 3.0040 & 2.8952 & 3.0412 \\
\hline & $\mathrm{N}$ & 186 & 186 & 186 & 186 \\
\hline & Std. Deviation & .86441 & .88473 & .87790 & .96552 \\
\hline
\end{tabular}

Table 5 indicates that the four domains (final product, price, location, and promotion) in terms of management occupied the first two positions in the fields of final product and promotion, where it obtained two arithmetic averages of 3.133 and 3.333 ), respectively, the standard deviation of 0.20656 and 0.59628 , respectively. While the administration of a local hotel chain got the first place in the areas of price and location with the mean arithmetic of 3.1953 and 2.996, respectively. The researcher attributes these results to the ability of local administrations to depend on local organization management in Aqaba. 
Table 6

Tests of Between-Subjects Effects

\begin{tabular}{|c|c|c|c|c|c|c|}
\hline Source & $\begin{array}{c}\text { Dependent } \\
\text { Variable }\end{array}$ & $\begin{array}{l}\text { Type III Sum of } \\
\text { Squares }\end{array}$ & df & Mean Square & $\mathbf{F}$ & Sig. \\
\hline \multirow[t]{4}{*}{ Corrected Model } & Product & $.000^{\mathrm{a}}$ & 0 & . & . & . \\
\hline & Price & $.000^{\mathrm{a}}$ & 0 & . & . & . \\
\hline & Place & $.000^{\mathrm{a}}$ & 0 & . & . & . \\
\hline & promotion & $.000^{\mathrm{b}}$ & 0 & & 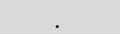 & \\
\hline \multirow[t]{4}{*}{ Intercept } & Product & 1656.048 & 1 & 1656.048 & 2216.345 & .000 \\
\hline & Price & 1678.503 & 1 & 1678.503 & 2144.356 & .000 \\
\hline & Place & 1559.044 & 1 & 1559.044 & 2022.878 & .000 \\
\hline & promotion & 1720.316 & 1 & 1720.316 & 1845.386 & .000 \\
\hline \multirow[t]{4}{*}{ Error } & Product & 138.232 & 185 & .747 & & \\
\hline & Price & 144.809 & 185 & .783 & & \\
\hline & Place & 142.581 & 185 & .771 & & \\
\hline & promotion & 172.462 & 185 & .932 & & \\
\hline \multirow[t]{4}{*}{ Total } & Product & 1794.280 & 186 & & & \\
\hline & Price & 1823.313 & 186 & & & \\
\hline & Place & 1701.625 & 186 & & & \\
\hline & promotion & 1892.778 & 186 & & & \\
\hline \multirow[t]{4}{*}{ Corrected Total } & Product & 138.232 & 185 & \multirow{4}{*}{\multicolumn{3}{|c|}{$\begin{array}{l}\text { a. } \mathrm{R} \text { Squared }=.000(\text { Adjusted R Squared }=.000) \\
\text { b. } \mathrm{R} \text { Squared }=.000(\text { Adjusted R Squared }=.000)\end{array}$}} \\
\hline & Price & 144.809 & 185 & & & \\
\hline & Place & 142.581 & 185 & & & \\
\hline & promotion & 172.462 & 185 & & & \\
\hline
\end{tabular}

To demonstrate the statistical significance of these differences between the different fields that we referred to in the previous tables, the researcher used the choice of regression variance $(\mathrm{F})$ and the results are presented in Table 6 . Table 6 indicates the difference between the arithmetic averages of the four fields, which were statistically significant in favor of each field that got a difference in the arithmetic mean over the other fields, where the value of the level of significance (alpha) reached zero in all areas and is less than $(0.05)$ which means that the differences are statistically significant.

\section{Conclusion}

The researcher has attributed the lack of use of the recycling of used products to the weak point in waste management in Jordan. It is at the stage of sorting at the source of the waste and then recycling, since this process requires a human effort and modern techniques that provide the opportunity to divide the waste and determine the percentage of recyclable ones. Aqaba hotels classified as waste sorting process, but there is no integrated waste management system in the Aqaba Special Economic Zone that includes reducing the volume of waste and reusing it in the same place or recycling it to another product and then recovering it in the Economic Production Department. Jordan does not have an integrated recycling system, but rather various attempts by civil organizations, as well as from the private sector. These attempts were on a narrow geographical level due to the lack of material capabilities, especially the availability of sorting and collection containers, equipment and cars (Jawabreh, 2017b; Kangun et al., 1991). In economic terms, the total cost of waste management in the Greater Amman Municipality is estimated at 12 million dinars, while the total losses amount to 7 million JD annually. While the Greater Amman Municipality generates reserve revenues from the reprocessing activities of cardboard, white paper, plastic products, iron and aluminum is relatively modest in Jordan (Jawabreh \& Al Sarayreh, 2017; Jawabreh, 2017a). The great interest in environmental awareness at all levels in the world coincided with the inclusion of economic institutions, social and environmental responsibility in marketing policies and activities. Hence, a new marketing thought emerged as one of the solutions to the negative effects of the degradation of the natural environment, known as environmental or green marketing. Competition has begun between institutions to adopt this marketing in order to ensure that it has a competitive advantage through marketing environmentally friendly products and through the realization of the right of consumers to live in a clean and safe environment. The social responsibility of the economic institutions translates into an ethical and voluntary framework in all its activities with the surrounding environment. As what the social responsibility of the institution achieves, it is improving its image in the community, especially among customers and workers, and its voluntary nature. This leads to improving the business environment and interdependence between different parties. As for the society as a whole, it achieves social stability due to the availability of a kind of justice, achieving the principle of equal opportunities and increasing the awareness of the members of the community. Social responsibility also included marketing activities through marketing a safe and easy to use product, and honesty in advertising its products without exaggeration (Lee et al., 2010; Liu et al., 2012; McIntosh,1990; Mahenc, 2007; Manaktola \& Jauhari, 2007; Marshall et al., 2014). It has also given the environment a great importance in this direction by paying attention to avoid environmental pollution and depletion of natural resources through various stages of production and marketing and through promoting the use of renewable and alternative energies, adopting a rational environmental policy as well as contributing to awareness campaigns and environmental protection. The consumer has long been exposed to many problems in his relationship with the economic institution, these problems took many forms of deception, fraud and misinformation through the marketing practices of the institution, and the transformation of the pursuit of various institutions to maximize profits and market share compared to competing institutions. They are trying to satisfy the needs and desires of consumers in various ways and achieve gains and profits regardless of the negative effects that may result (such as some undesirable consumer patterns that harm the society and the environment). Therefore, the consumer became the weak party in the marketing 
equation. Organizations sell all the products that they manufacture; therefore, it is their responsibility to produce clean products at every step of their operations. This method assumes considering that everyone is involved in all parts of the processes, if the parts are contaminated or are wasting energy, the final product and its role in life will be reflected on the product as a whole. The fundamental basis on which organizations determine prices is the total cost of the product, the price must reflect the cost of the product and therefore it is very important that it corresponds to the true value of the product offered to the customer. As for green products, there has been an increase in the prices of these products because they have a higher value that reflects not only the fact that they do not harm the environment but also reflect other aspects such as the search for alternative materials and the protection of natural resources; which includes the high costs of research and development. Many organizations have realized that green marketing represents a market opportunity that may give the organization a competitive and possibly sustainable advantage. In fact, most organizations compete in the market for quick profits regardless of the negative effects on the environment. A person looking carefully at the market competition recognizes that this is a strategic competitive way out to take the organization to another type of competition, especially with the growing environmental awareness among customers and their gradual conversion to green customers, and the advantage of this strategic approach is that the formal and informal organizations promote environmental trends naturally and continuously through the various media. This is free assistance and support from these actors for the promotion efforts of organizations that adopt the green marketing approach, and therefore this approach will be profitable, especially in the long-term (Marshall et al., 2013; Martínez, 2015; Masadeh et al., 2019). Green products usually carry a price addition because of the additional costs of making the product environmentally viable, since green products usually require considerable efforts and costs in the field of research and development, adjustment in production methods in line with the goal of efficient use of energy, and reducing damage and loss in the use of raw materials. Distributive outlets are the key link in achieving the goal of any organization, namely, the arrival of their products to the final customer, as they are the intermediary institutions aimed at making the product or service available for use or consumption, sellers or distributors may benefit from the application of green marketing entrance through strengthening the links with the producers and their customers due to the continuation of the relationship between the two parties through the (two-way) distribution system, which depends heavily on recycling, i.e. the process of returning waste or residues of used materials (such as empty plastic bottles) to the place of production, selling them instead of throwing them away for money, or getting new products. In spite of the costs and efforts incurred by the recycling process, a number of institutions have made the process a competitive advantage in their favor, by sustaining the relationship with customers and distributors, building new techniques that distinguish them from others, and by gaining the support of environmental groups. Promotion is one of the key elements in the green marketing mix, because through it the organization conveys its environmental orientations and image to customers with the transfer of its own marketing message for the products or services it offers. Promotion in green marketing may take several forms such as advertising, promotion (activation) of sales, public relations, personal sale, packaging, in addition to environmental labels. The latter is the type of labels used to provide assurances to the customer that branded products meet environmental standards. There was negligence of environmental issues in the marketing strategy due to limited laws binding on environmental protection. These were merely recommendations that were indicative rather than mandatory. Environmental movement activity emerged and put pressure on governments to enact deterrent laws to protect the environment; economic institutions began to integrate the environmental dimension in marketing policies, but cautiously, because they feared for business and profits to decrease as a response to the laws imposed. They also began to conduct research and development to create environmental advantages of their products that correspond and preserve the environment. Economic institutions began to take into account the environmental concerns in the marketing strategy in light of the development of environmental protection laws and political awareness of the importance of the latter and this appeared through the change of production processes and design products.

\section{References}

Ann, G. E., Zailani, S., \& Abd Wahid, N. (2006). A study on the impact of environmental management system (EMS) certification towards firms' performance in Malaysia. Management of Environmental Quality: An International Journal, 17(1), 73-93.

Alananzeh, O., Al-Badarneh, M., Al-Mkhadmeh, A., \& Jawabreh, O. (2018). Factors influencing MICE tourism stakeholders decision making: The case of Aqaba in Jordan. Journal of Convention \& Event Tourism, 20(1), 24-43.

Alananzeh, O. A., Amyan, M. M., ALghaswyneh, O. F. M., Shatnawi, H., \& Jawabreh, O. (2015). Managing promoting tourism product of the golden triangle in Jordan. International Journal of Humanities and Social Science, 5(9), 197-207.

ALsarayreh, M. N., Jawabreh, O. A., ALkharabsheh, K. S., \& Aldahamsheh, M. M. (2011). Tourism promotion through the internet (websites)(Jordan as a case study). Asian Social Science, 7(6), 125.

Arthur, D., Motwani, R., Sharma, A., \& Xu, Y. (2009, December). Pricing strategies for viral marketing on social networks. In International Workshop on Internet and Network Economics (pp. 101-112). Springer, Berlin, Heidelberg.

Baker, M. A., Davis, E. A., \& Weaver, P. A. (2014). Eco-friendly attitudes, barriers to participation, and differences in behavior at green hotels. Cornell Hospitality Quarterly, 55(1), 89-99.

Berezan, O., Raab, C., Yoo, M., \& Love, C. (2013). Sustainable hotel practices and nationality: The impact on guest satisfaction and guest intention to return. International Journal of Hospitality Management, 34, 227-233.

Cengiz, E., Cengiz, F., Cavusoglu, M., \& Cobanoglu, C. (2019). Managerial perceptions of cost-system obsolescence and factors that might affect it. International Journal of Contemporary Hospitality Management, 31(7), 2884-2913.

Chan, E. S., \& Hsu, C. H. (2016). Environmental management research in hospitality. International Journal of Contemporary Hospitality Management, 28(5), 886-923.

Chan, E. S. (2013). Gap analysis of green hotel marketing. International Journal of Contemporary Hospitality Management, 25(7), 10171048. 
Chen, C., \& Schwartz, Z. (2008). Room rate patterns and customers' propensity to book a hotel room. Journal of Hospitality \& Tourism Research, 32(2), 287-306.

Dholakia, U., \& Bagozzi, R. P. (2001). Consumer behavior in digital environments. Digital Marketing, 163-200.

DiPietro, R. B., Cao, Y., \& Partlow, C. (2013). Green practices in upscale foodservice operations. International Journal of Contemporary Hospitality Management, 25(5), 779-796.

El Dief, M., \& Font, X. (2010). The determinants of hotels' marketing managers' green marketing behavior. Journal of Sustainable Tourism, 18(2), 157-174.

Fraj, E., Martinez, E., \& Matute, J. (2011). Green marketing strategy and the firm's performance: the moderating role of environmental culture. Journal of Strategic Marketing, 19(4), 339-355.

Fuller, D.A. (1999), Sustainable Marketing: Managerial-Ecological Issues, Sage, Thousand Oaks, CA.

Ginsberg, J.M., \& Bloom, P.N. (2004). Choosing the right green marketing strategy. MIT Sloan Management Review, 46(1), 79-84.

Henion, K.E. (1972). The effect of ecologically relevant information on detergent sales. Journal of Marketing Research, 9(2), $10-14$.

Jawabreh, O., \& Alsarayreh, M. (2017). Analysis of job satisfaction in the hotel industry: a study of hotels five-Stars in Aqaba special economic zone authority (AZEZA). International Journal of Applied Business and Economic Research, 15(19), 389.

Jawabreh, O. (2017a). Distinction of Jordan as a destination for religious tourism. Journal of Environmental Management and Tourism, $6(22), 1171-1182$.

Jawabreh, O. (2017b). An exploratory study of the motives of Jordanian out bound tourism and its impact on the development of tourism in Jordan. International Journal of Applied Business and Economic Research, 15(19 Part-II), 443-467.

Kangun, N., Carlson, L., \& Grove, S.J. (1991). Environmental advertising claims: a preliminary investigation. Journal of Public Policy and Marketing, 10(2), 47-58.

Kapelianis, D., \& Strachan, S. (1996). The price premium of an environmentally friendly product. South African Journal of Business Management, 27(4), 89-96.

Kim, Y. K., Forney, J., \& Arnold, E. (1997). Environmental messages in fashion advertisements: Impact on consumer responses. Clothing and Textiles Research Journal, 15(3), 147-154.

Kotler, P., \& Keller, K. L. (2016). Marketing management (15th global ed.). England: Pearson.

Lee, J. S., Hsu, L. T., Han, H., \& Kim, Y. (2010). Understanding how consumers view green hotels: how a hotel's green image can influence behavioural intentions. Journal of Sustainable Tourism, 18(7), 901-914.

Liu, X., Wang, C., Shishime, T., \& Fujitsuka, T. (2012). Sustainable consumption: Green purchasing behaviours of urban residents in China. Sustainable Development, 20(4), 293-308.

McIntosh, A. (1991). The impact of environmental-issues on marketing and politics in the 1990s. Journal of the Market Research Society, 33(3), 205-217.

Mahenc, P. (2007). Are green products over-priced?. Environmental and Resource Economics, 38(4), 461-473.

Jauhari, V., \& Manaktola, K. (2007). Exploring consumer attitude and behaviour towards green practices in the lodging industry in India. International journal of contemporary hospitality management, 19(5), 364-377.

Marshall, R., Bibby, D., \& Na, W. (2014). Making Sense of Marketing Decision Systems through Pictorial Representation: Decision System Analysis', Field Guide to Case Study Research in Business-to-business Marketing and Purchasing (Advances in Business Marketing and Purchasing, Volume 21).

Marshall, R. , Bibby, D. , \& Na, W. (2013). Making sense of complex marketing decision systems: Decision system analysis. International Journal of Business \& Economics, 12(2), 121-130.

Martínez, P. (2015). Customer loyalty: exploring its antecedents from a green marketing perspective. International Journal of Contemporary Hospitality Management, 27(5), 896-917.

Masadeh, R., Alananzeh, O., Jawabreh, O., Alhalabi, R., Syam, H., \& Keswani, F. (2019). The association among employees communication skills, image formation and tourist behaviour: perceptions of hospitality management students in Jordan. International Journal of Culture, Tourism and Hospitality Research, 13(3), 257-272.

Mathur, L.K., \& Mathur, I. (2000). An analysis of the wealth effects of green marketing strategies. Journal of Business Research, 50(2), 193-200.

Osarenkhoe, A. (2003). The economics of strategic marketing management: a discourse on the conceptual and operational definition of customer relationship management. Paper presented at the 12th International Symposium on Management of Technology, Nancy, France, May 2003 and at The 17th Nordic Conference on Business Studies under the auspices of Scandinavian Academy of Management in Reykjavik, Iceland, August.

Rand, W., \& Rust, R. (2011). Agent-based modeling in marketing: Guidelines for rigor. International Journal of Research in Marketing, 28(3), 181-193.

Saleh, M. M. A., \& Jawabreh, O. A. A. (2020). Role of environmental awareness in the application of environmental accounting disclosure In tourism and hotel companies and its impact on Investor's decisions in Amman Stock Exchange. International Journal of Energy Economics and Policy, 10(2), 417-426.

Xiong, L., \& Hu, C. (2010). Harness the power of viral marketing in hotel industry: a network discount strategy. Journal of Hospitality and Tourism Technology, 1(3), 234-244.

Zhao, W., \& Zheng, Y.-S. (2000). Optimal dynamic pricing for perishable assets with nonhomogeneous demand. Management Science, 46(3), 375-88.

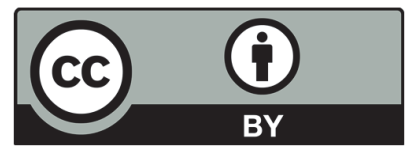

(C) 2020 by the authors; licensee Growing Science, Canada. This is an open access article distributed under the terms and conditions of the Creative Commons Attribution (CC-BY) license (http://creativecommons.org/licenses/by/4.0/). 